Magdalena Garnczarska

Instytut Historii Sztuki

Uniwersytet Jagielloński

http://dx.doi.org/10.18778/8088-249-2.15

\title{
HISTORIA BUDUJĄCA O BARLAAMIE I JOZAFACIE JAKO HISTORIA BUDUJĄCA DLA CHRZEŚCIJAN ŻYJĄCYCH POD ISLAMSKIM PANOWANIEM NA PRZYKŁADZIE MINIATUR W IVIRON COD. 463
}

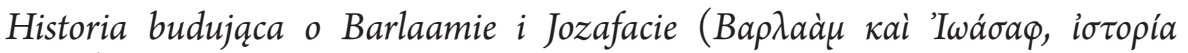
$\left.\psi v \chi \circ \varphi \varepsilon \lambda \eta \varsigma^{\prime}\right)$ to jedna $\mathrm{z}$ najlepszych pod względem artystycznym średniowiecznych bizantyńskich powieści pisanych prozą [Jurewicz 2007: 226]. Opowiedziano $\mathrm{w}$ niej historię przyjęcia chrześcijaństwa przez indyjskiego księcia Jozafata, dając przy tym przykład gorącej apologii chrześcijańskiego ascetyzmu.

Legenda o Barlaamie i Jozafacie jest uważana za parafrazę jednej z biografii Buddy (ok. 563-483 przed Chr.) [Borowska 2002a: 66]. Podobieństwo księcia Jozafata do Buddy zauważono w 1612 r., ale kwestię tę w bardziej szczegółowy sposób omówili dopiero w roku 1859 - niezależnie od siebie - dwaj badacze, M. Laboulaye i F. Liebrecht. Za ich sprawą problem występowania w schrystianizowanej wersji elementów zaczerpniętych z buddyzmu, a także jej zależności od indyjskich tekstów o życiu Buddy, stał się jednym $\mathrm{z}$ wiodących w literaturze przedmiotu [Pitts 1981: 3-16; zob. także: Lang 1967: X-XV; Almond 1987: 396-400; King 2002: 105-112].

Inne istotne zagadnienie badawcze stanowi także problem autorstwa tłumaczenia na język grecki. Badacze nie są też zgodni co do języka, z którego dokonano przekładu. W starszej literaturze zwykło się przyjmować, że Historię budująca o Barlaamie i Jozafacie na potrzeby kultury bizantyńskiej przystosował święty Jan z Damaszku (ok. 675 - ok. 750). Ta atrybucja opiera się na utożsamieniu pobożnego mnicha Jana z klasztoru świętego Saby pod Jerozolimą - wymienionego we wstępie dzieła jako ten, który przyniósł budujący tekst z dalekiego kraju Etiopów, zwanego ziemią Hindusów (w starożytności nierzadko łączono mieszkańców Indii z Etiopami, co mogło wynikać ze wzmianki Homera w Odysei, w której to wyróżnił dwa szczepy Etiopów, zachodni i wschodni; Hom. Od. 1.21-25) - zJanem Damasceńskim (dzieło nadto zawiera sporo parafraz z tekstów tego świętego). Należy jednak zauważyć, że nie jest znana żadna grecka redakcja tekstu sprzed wieku XI, nie ma także wzmianek świadczących o znajomości w Bizancjum legendy o Barlaamie i Jozafacie sprzed XI w. [Lang 1967: XX-XXII]. Stąd też wydaje 
się, iż bezpieczniej jest uznać, że na początku tekstu wspomniano bliżej nieznanego mnich Jana z klasztoru św. Saby, który przyniósł ze sobą znajomość historii o Barlaamie i Jozafacie, nie napisano bowiem, że to on miał dokonać przekładu.

Obecnie zwykle uznaje się, że tekst grecki opiera się na wersji w języku gruzińskim [Lourié 2011: 136-138]. Niekiedy zaś wskazuje się, że tłumaczenia z gruzińskiego dokonał Georgios Eutymios (ur. pomiędzy 955 a 960, zm. 13 V 1028) [Jeffreys i in. 1991: 256]. Jego wywodzący się z kręgów gruzińskiej arystokracji ojciec - który po narodzinach syna został mnichem - Jan z Iberii wraz z Tornikiosem, innym mnichem, założył (979/980) klasztor Iwiron na Athos [zob. Ceran 2002: 223-224], w którym Eutymios był w latach 1005-1019 igumenem. Do jego głównych zasług należy zorganizowanie przy klasztorze skryptorium oraz przełożenie na język gruziński wielu dzieł (głównie teologicznych, w tym św. Jana z Damaszku, i hagiograficzych) napisanych po grecku [Kazhdan 1991: 757]. Doskonała znajomość greki przez Eutymiosa wynikała z tego, że w dzieciństwie był przez kilka lat zakładnikiem na konstantynopolitańskim dworze, poręczając lojalność gruzińskiej ludności względem cesarza [Lang 1967: XXVIII-XXIX]. Jego imię, jako autora greckiego tłumaczenia, po raz pierwszy pojawiło się w XI-wiecznym manuskrypcie (Wenecja, Marc. Gr. VII, 26), zaś w XIV-wiecznym rękopisie z łacińską wersją (1048 r.), znajdującym się w Bibliotece Narodowej w Neapolu (cod. VIII, B. 10), uznano Eutymiosa nie tylko za tłumacza, lecz także podkreślono, że on jako pierwszy przełożył tekst na grekę (z języka mieszkańców Indii). Informację tę podał także jego kuzyn, a zarazem biograf oraz następca w klasztorze Iwiron, Jerzy Hagioryta (1009-1065), w żywocie Eutymiosa, który spisał około 1045 r. [Almond 1987: 401-402].

Uznając gruzińskie pośrednictwo, pozostaje rozważyć także datowanie i źródło edycji gruzińskiej. Badacze najczęściej uznają, że dwie najstarsze zachowane wersje gruzińskie (jedna z nich - w rękopisie nr 140 z Biblioteki Patriarchatu w Jerozolimie - przekazuje najstarszy obecnie znany schrystianizowany tekst legendy, który, na podstawie przesłanek filologicznych, jest datowany na wiek IX) stanowią adaptację starszych arabskich tekstów [Lourié 2011: 136-139]. Wiadomo zaś, że w kręgu kultury muzułmańskiej znane były teksty dotyczące Buddy. Arabski historyk i geograf al-Masudi (ok. 896-956), opisując panowanie abbasydzkiego kalifa al-Mahdiego (ok. 745-785), wspomniał, że wówczas Bagdad został wręcz zalany tekstami, będącymi tłumaczeniami dzieł heretyków i fałszywych proroków. Wśród nich zaś znajdowały się przynajmniej trzy o Buddzie (zwanym tam al-Budd lub Budhasaf) - na co wskazuje traktat zwany Kitab al-Fihrist (spisany w latach 987-988) [Lang 1967: XVIII-XX]. Dowody na arabskie pośrednictwo mają charakter przede wszystkim językowy i dotyczą np. przekładu imion własnych na gruziński, a następnie grecki [Pitts 1981: 4; Lang 1967: $\mathrm{XXV}$. Zwykle wskazuje się przy tym, że środowiskiem, w którym mogło dojść do zredagowania chrześcijańskiej wersji legendy, była Palestyna (gdzie istniało też żywe środowisko gruzińskie, związane z klasztorem św. Katarzyny na Synaju). 
Nie ma jednak zgody w kwestii czasu powstania tej pierwotnej wersji - proponowany jest wiek VII lub IX [Lourié 2011: 143-144; Lang 1967: XXIII-XXIV].

Mimo nierozstrzygnięcia wielu problemów badawczych, związanych z tekstem Historii budującej o Barlaamie i Jozafacie, pewne jest, że legenda bardzo szybko stała się w Bizancjum niezwykle popularna (zachowało się ok. 140 rękopisów z okresu XI-XVI w. [Jurewicz 2007: 226]) i od połowy XI w. zaczęła docierać do innych chrześcijańskich krajów. Grecka wersja była podstawą przekładu na łacinę, (który następnie posłużył do tłumaczeń na języki zachodnioeuropejskie), a także język staro-cerkiewno-słowiański i arabski [Lang 1967: XXXII-XXXIV], i przyczyniła się do powstania kulturowego fenomenu, polegającego na ogromnej popularności legendy, która stała się szeroko znana zarówno na Wschodzie, jak i Zachodzie [zob. Cordoni, Meyer 2015].

Zważywszy na poczytność historii o Barlaamie i Jozafacie w Bizancjum, warto zastanowić się, z czego ona wynikała. Niewątpliwie istotną rolę musiały odegrać walory literackie dzieła, napisanego staranną klasyczną greką z elementami koinè i odznaczającego się wartką akcją, osadzoną nadto w egzotycznym otoczeniu. Wpisywało się ono także w nurt rozwijającej się od wieku XI powieści chrześcijańskiej, łącząc w sobie interesujące wydarzenia oraz elementy wykładni religii chrześcijańskiej [Jurewicz 2007: 226; zob. także: Bádenas de la Peña 2015: 2-16]. W ten sposób też Historia budująca o Barlaamie i Jozafacie z jednej strony stanowiła pewną kontynuację tradycji powieści antycznej - przedstawiając niezwykłe wydarzenia w odległym kraju oraz wyraziste postaci - z drugiej zaś, czerpiąc obficie z dorobku literatury chrześcijańskiej, rozwinięto w niej wątki religijne o wydźwięku moralizatorskim [zob. Bolton 1958: 359-366], niemal zupełnie usuwając motywy erotyczne, będące jedną z cech konstytutywnych gatunku w antyku [zob. Holzberg 2003, zwł. s. 13-43; Borowska 2002b: 424-425]. Co więcej dwaj tytułowi bohaterowie zostali uznani za świętych i włączono ich do kalendarza liturgicznego zarówno w Kościele Wschodnim (26 sierpnia), jak i Zachodnim (27 listopada) [Almond 1987: 393-394].

W kontekście niezwykłej popularności historii Barlaama i Jozafata warto zastanowić się, czy nie osadzała się ona także na prawdziwie budującym przesłaniu opowieści, mówiącym o nawróceniu na chrześcijaństwo indyjskiego księcia i jego ojca. Mogło ono bowiem znajdować uznanie u bizantyńskich czytelników obserwujących kolejne podboje muzułmańskich władców, w wyniku których część $\mathrm{z}$ nich znalazła się pod obcym panowaniem i musiała się odnaleźć w nowej rzeczywistości, zachowując swe wyznanie. Choć Arabowie, którzy w VII w. zaczęli zajmować bizantyńskie tereny, nie prześladowali chrześcijan i nie zmuszali ich siłą do przyjęcia islamu, lecz zwykle zadowalali się pobieraniem haraczu, to jednak chrześcijanie podlegali różnym formom dyskryminacji [zob. Woźniak 2015: 428-457], co mogło ewokować marzenia o nawróceniu nowych panów. Z kolei w połowie wieku XI, kiedy to legenda była już znana i popularna w Bizancjum, poczucie zagrożenia ze strony muzułmanów było już bardzo silne, ponie- 
waż pogrążone w kryzysie Cesarstwo właściwie utraciło możliwość skutecznej obrony swych granic przed nimi [zob. Bonarek 2011].

Do bliższego zapoznania się z powieścią przydatne są miniatury z bizantyńskiego rękopisu przechowywanego w klasztorze Iwiron na Athos (cod. 463), gdyż nie tylko w plastyczny i szczegółowy sposób ukazują poszczególne wydarzenia, ale także dają interesujący wgląd w bizantyńskie wyobrażenia dotyczące tej egzotycznej historii. Poza tym dzieło potwierdza popularność legendy o Barlaamie i Jozafacie w Bizancjum, w związku, z którą już w wieku XI opowieść zyskała swój wyraz w sztuce. Wówczas bowiem powstał (w malarstwie miniaturowym) obszerny cykl narracyjny ukazujący dzieje tytułowych bohaterów [Smorąg Różycka 1993: 15; zob. także: Der Nersessian 1937: 18-21].

Kodeks numer $463(17 \times 23 \mathrm{~cm}, 135$ fols., tempera i złoto na pergaminie), datowany na lata 1075-1125, należy do grupy sześciu bogato ilustrowanych greckich rękopisów Historii budujacej o Barlaamie i Jozafacie [Anderson 1997: 242]. Zawiera on 80 miniatur (ujętych w pola obrazowe o kształcie poziomych prostokątów, które opływa tekst - tylko jedna ilustracja, fol. 1v, jest całostronicowa, zawiera ona wizerunek św. Jana z Damaszku, uważanego za autora), na których ukazano około 200 epizodów, które nie tylko obrazują poszczególne wydarzenia, ale również opowiadane przez Barlaama przypowieści. Rękopis zasadniczo zachował się w bardzo dobrym stanie: miniatury na tylko jednej stronie (fol. 126v) są zupełnie zniszczone, a kilka ostatnich jest nieco wytartych. Obok oryginalnego tekstu w języku greckim znajduje się także, później dodane, tłumaczenie w języku starofrancuskim [Kadas 1997: 212-213; Toumpouri 2015: 400-401].

Utwór rozpoczyna się krótkim wstępem, w którym autor wyjaśnił cel spisania historii z odległej krainy. Podkreślił on, że na przykładzie wiernych wyznawców Chrystusa, którzy nie ugięli się nawet pod groźbą męczeńskiej śmierci, chciał dać budujący przykład dla innych chrześcijan i zachęcić ich do dojrzałości w wierze, która pomagając uwolnić się od zgubnych namiętności, umożliwia dążenie

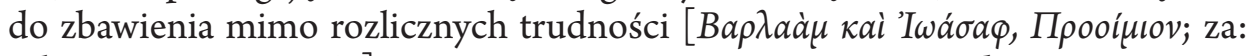
John Damascene 1967]. Następnie rozpoczyna swą opowieść, która ma miejsce

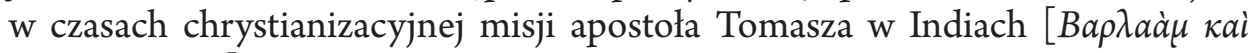
'I $\omega a ́ \sigma \alpha \varphi$, I 3-5]. Indie oraz działalność Tomasza ukazano na dwóch miniaturach (fols. 3r, 4r; reprodukcje miniatur cod. 463: Pelekandis 1975: 60-91). Kraj przedstawiono jako usiany pagórkami, wśród których wybudowano miasta otoczone murami, jego mieszkańców zaś jako ludzi o ciemnej karnacji, ubranych w tuniki sięgające kolan i w turbanach na głowach. Apostoł - odziany w antyczny chiton i himation, zgodnie z bizantyńską tradycją ikonograficzną - nauczając Hindusów o Chrystusie, wielu z nich zdołał przekonać do nowej wiary i poprzez chrzest włączył do chrześcijańskiej wspólnoty. Nie dotyczyło to jednak króla Abennera, władcy potężnego i odnoszącego wiele zwycięstw, ale także czczącego greckich

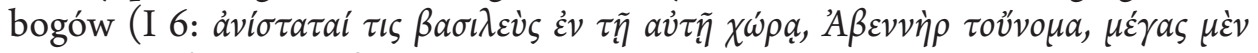

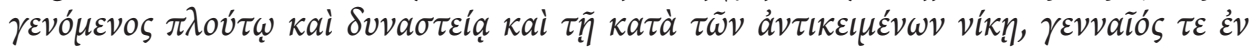




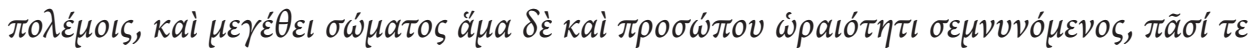

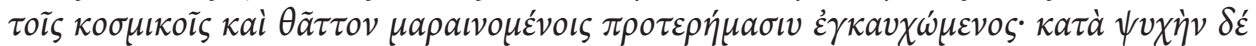

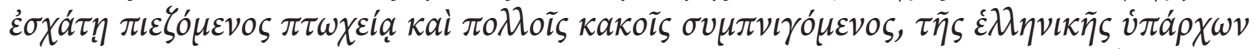

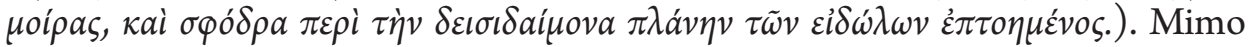
wszelkich luksusów nie był on szczęśliwy, ponieważ pozostawał bezdzietny. Nie podobało mu się także, że na chrześcijaństwo przechodzi coraz więcej jego poddanych, tym bardziej że wielu z nich decydowało się na życie mnisze. W związku $\mathrm{z}$ tym rozpoczął okrutne prześladowania, a następnie polecił chrześcijan wygnać

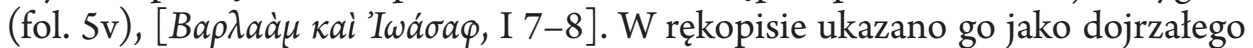
mężczyznę o ciemnym zaroście, jasnej cerze (ciemną wyróżniają się tylko słudzy oraz zwykli ludzie) i ubranego w długą, orientalną szatę oraz turban (fol. 4v), co stanowi pewien wyjątek, ponieważ w innych rękopisach (poza cod. Cambridge 338) przedstawiano go w stroju cesarza bizantyńskiego i z koroną $\mathrm{w}$ formie kamelaukionu lub stemmy [Smorąg Różycka 1993: 23]. Od złych zamiarów nie zdołał Abennera odwieść nawet jeden z najważniejszych satrapów, który sam się nawrócił, a następnie został mnichem (fol. 7r). Wyłożył on królowi zasady wiary chrześcijańskiej, co tylko władcę rozwścieczyło i popchnęło ku jeszcze większym

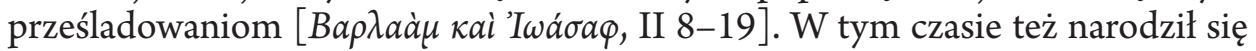

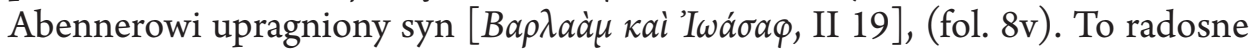
wydarzenie jednak nie zmieniło jego wrogiej postawy - na jednej z miniatur widzimy dwóch mnichów wrzuconych do ognistego pieca (fol. 11v) - tym bardziej, że od chaldejskich astrologów dowiedział się, że jego następca, któremu nadał imię Jozafat, odrzuci nie tylko pogaństwo, ale także ziemskie panowanie

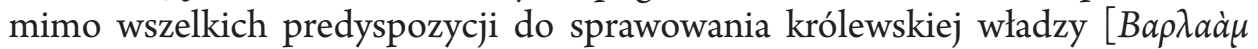

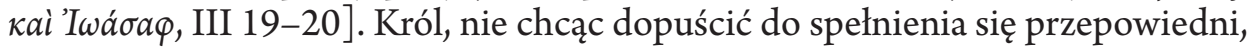
zdecydował się umieścić syna w specjalnym pałacu, zapewniającym izolację od całego świata i związanych z nim trosk. Nie chciał bowiem, aby Jozafat natknął się na jakiekolwiek przypadkowe osoby, które mogłyby mu uświadomić, że prawdziwe życie wygląda zupełnie inaczej niż w pałacu - mędrcy przestrzegli króla, że syn zmieni swe życie pod wpływem zetknięcia się z ludźmi chorymi, starymi i biednymi (stąd jego słudzy byli młodzi i w pełni zdrowi). Jednocześnie kontynuował

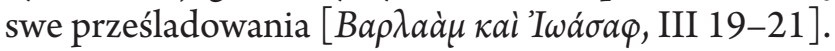

Gdy Jozafat dorósł, zapragnął poznać prawdziwą przyczynę swego odcięcia od świata. Wszystko wytłumaczył mu najbliższy z opiekunów. Ostatecznie też choć nie bez problemów - książę zdołał przekonać swego ojca do zezwolenia mu

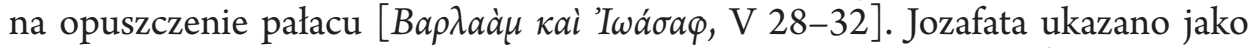
młodzieńca ubranego podobnie jak jego ojciec, czyli w długą szatę (barwy jasnego błękitu) i turban (fol. 14r). Kiedy po raz pierwszy udał się (w towarzystwie sług) za miasto, od razu natknął się na ślepca i trędowatego (fol. 15r) oraz starca (fol. 15v), co go mocno zafrapowało - nigdy wcześniej bowiem nie miał do czynienia z takimi ludźmi - ale i zasmuciło, tak że jego dotychczasowe beztroskie i przyjemne życie zostało zupełnie zmącone, ponieważ te spotkania wciąż 


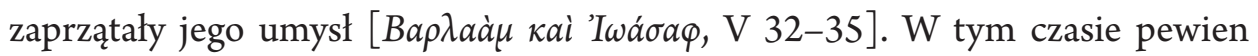
świętobliwy mnich imieniem Barlaam - wiodący ascetyczne żywot w swej pu-

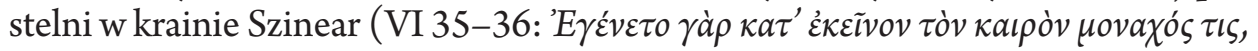

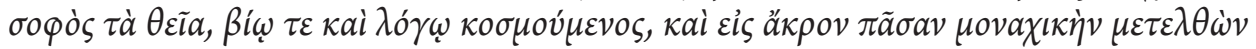

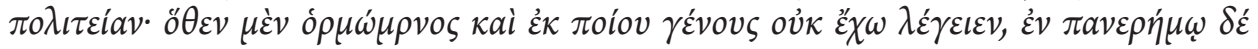

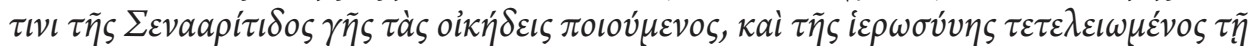

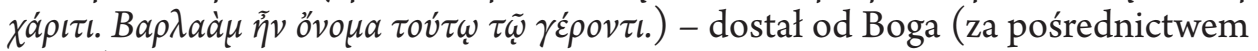
anioła) polecenie udania się do Indii i nawiązania kontaktu z księciem Jozafatem

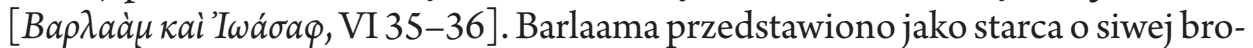
dzie, ubranego w długą szatę i ciemny płaszcz (fol. 16v). Mnich, pouczony przez anioła, przebrał się za kupca i przybył do pałacu pod pretekstem zaprezentowania Jozafatowi drogocennej gemmy (fols. 18r, 19v). Podstęp powiódł się, ponieważ Barlaam został dopuszczony przed książęce oblicze i rozpoczął z młodzieńcem

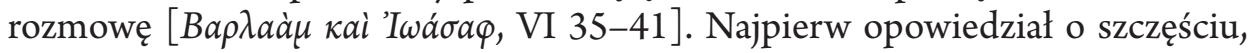
jakie daje mu wiara, następnie zaś rozpoczął swój wykład, w którym przekazał Jozafatowi historię Zbawienia, a także wiele pouczeń opartych o tekst Pisma Świętego. Przytoczył też liczne przypowieści [zob.: Bádenas de la Peña 2015: 18-19]. Część ta zajmuje rozdziały od VI do X (fols. 20r-47v).

Wysiłki pobożnego i mądrego mnicha przyniosły wspaniały owoc, ponieważ

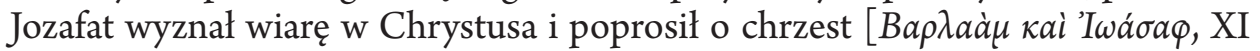
86-87]. Barlaam zaś zgodził się go ochrzcić (fol. 53v). Nim jednak do tego doszło, mnich bardzo dokładnie pouczył Jozafata o chrześcijańskich powinnościach, a także opisał mu życie pustelnicze - przy tej okazji pojawily się kolejne przypo-

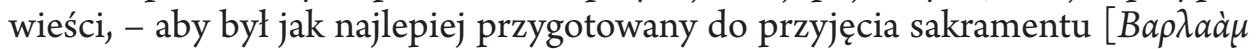

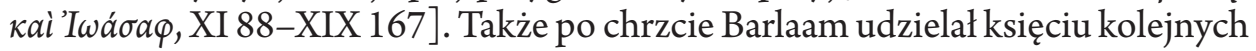

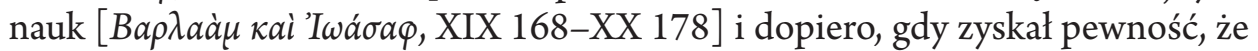
Jozafatem nic nie zachwieje, zdecydował się na opuszczenie swego ucznia (fols.

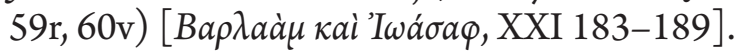

$\mathrm{W}$ tym też czasie Abenner za sprawą Zardana, jednego z opiekunów syna, dowiedział się o wizycie Barlaama i jej rezultacie, po czym wraz ze swym doradcą Arachesem obmyślił plan odciągnięcia Jozafata od chrześcijaństwa (fols. 63r, 64r). Zaczął od okrutnych prześladowań mnichów, których torturowano, po-

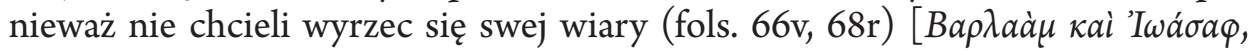
XXII 191-XXIII 203]. Król, niezadowolony z postawy mnichów, którzy woleli męczeństwo, zdecydował się za radą Arachesa skorzystać z pomocy maga Nacho-

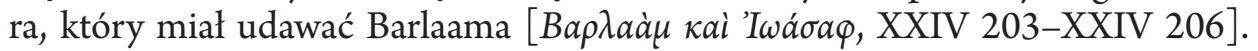
Nachora ukazano jako starca z siwą brodą, ubranego w długą, ciemną szatę, a więc właściwie tak samo, jak wcześniej Barlaama (fols. 69r, 69v). Abenner ponadto osobiście udał się do syna, aby przekonać go do powrotu do idolatrii, ale doznał dotkliwej porażki - Jozafat bowiem, zamiast usłuchać, dał mu obszerny

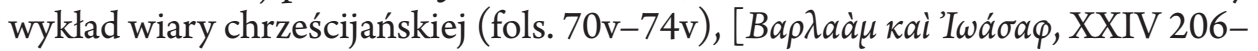
XXV 232]. Zagniewany i bezradny władca zaproponował debatę na temat religii 
- chrześcijan miał reprezentować Barachias (przyjaciel Jozafata). Przybył także podszywający się pod Barlaama Nachor, ale szybko został zdemaskowany (fol. 77r). Następnie zaś - za sprawą Jozafata - mag porzucił pogaństwo, na dowód czego wygłosił długą mowę, będącą parafrazą Apologii Arystydesa z Aten (zm. ok.

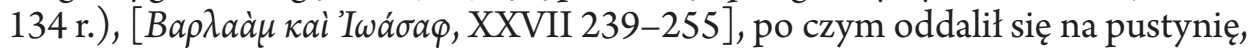

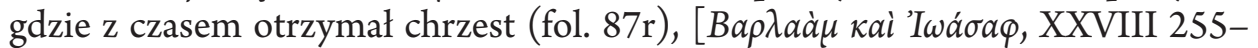
260]. Abenner, - który sam zaczął powątpiewać w moc swych bogów - uciekł się jeszcze do pomocy czarnoksiężnika Theudasa. Przedstawiono go jako starca o białej brodzie i długich włosach w nieładzie, odzianego w szatę z sierści (fols. 88v-90v). Theudas zaproponował, aby posłać do Jozafata piękną księżniczkę, mającą skłonić go do zmiany (fol. 95r). Książę oparł się jej wdziękom - doznając we śnie wizji raju i piekła (fols. 100r, 101r) - tak, że sam mag postanowił go przekonać do porzucenia chrześcijaństwa. Skutek okazał się jednak odwrotny, gdyż

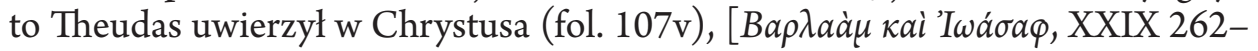
XXXII 302]. Bezradny Abenner podzielił królestwo, dając jego część we władanie Jozafatowi (fol. 108r). Ten zaś zaczął od zniszczenia pogańskich świątyń i wybudowania kościoła w głównym mieście oraz chrystianizacji mieszkańców, którym też rozdał swe bogactwa (fols. $110 \mathrm{r}-113 \mathrm{v}$ ). W rezultacie jego państwo rozkwitało, co ostatecznie przekonało Abennera, że to chrześcijaństwo jest jedyną prawdziwą wiarą, do czego przyznał się w liście do Jozafata (fols. 114v-116r). Książę więc - niezwykle uradowany wiadomością - udał się do ojca i pouczył go

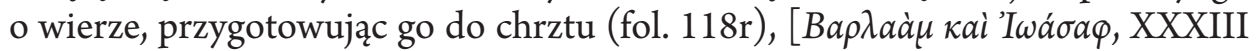
303-XXXV 321]. Dzięki temu nie tylko obie części królestwa pomyślnie się rozwijały, ale także Abenner, który wkrótce zachorował, zmarł pogodzony z Bogiem

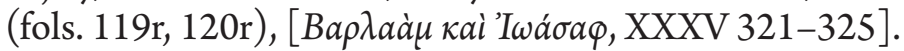

Jozafat, będący jedynym władcą, szybko zapragnął jednak oddalenia się do pustelni, co wzbudziło u jego poddanych ogromny smutek, który został nieco uśmierzony przez wybór Barachiasa na jego następcę (fols. 121r-123v),

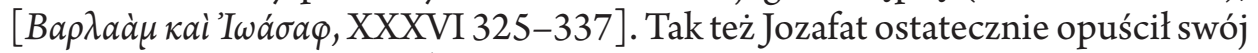
lud i odszedł na pustynię (tam ukazano go jako dojrzałego mężczyznę z ciemną brodą i w krótkiej tunice), a po dwóch latach zdołał odnaleźć Barlaama (fol. 128v), któremu następnie towarzyszył przez kolejne lata - aż do śmierci swego

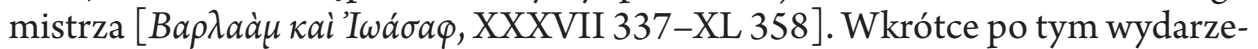
niu Jozafat oglądał we śnie niebo (fol. 133r) i rozmawiał tam z Barlaamem, uznanym za świętego. Niedługo później zaś umarł i został pogrzebany przy Barlaamie

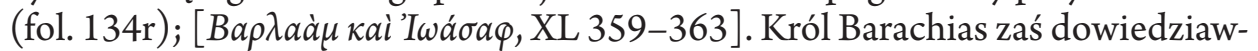
szy się od świętobliwego mnicha o śmierci swego przyjaciela (fol. 135v), zdecydował się na translację ciał Barlaama i Jozafata, którym wierni zaczęli oddawać

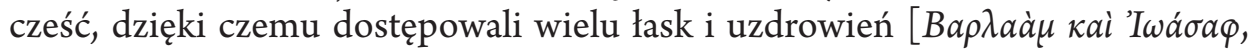
XL 364-365].

Narrator zakończył swą opowieść zachętą do modlitwy za pośrednictwem

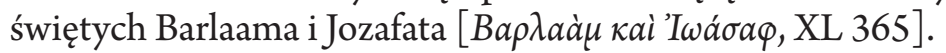


Historia budująca o Barlaamie i Jozafacie dawała więc swym czytelnikom konkretne wzory do naśladowania, przede wszystkim - co ukazano jako szczyt chrześcijaństwa - proponowała życie ascetyczne, odrzucające doczesność, ale i dla tych, którzy nie chcieli lub nie mogli zdecydować się na taki radykalizm, stanowiła historię budująca, ponieważ prezentowała prawdziwych wyznawców Chrystusa, którzy nie porzucili swej wiary mimo okrutnych prześladowań. Ta postawa zaś mogła krzepić chrześcijan żyjących pod muzułmańskim panowaniem, którzy - choć nie cierpieli tak jak mieszkańcy Indii - mogli jednak ulegać pokusie przejścia na islam, aby stać się pełnoprawnymi członkami społeczeństwa. Co więcej dzieje Barlaama i Jozafata wyraźnie pokazywały, że nawet najbardziej zagorzali przeciwnicy chrześcijaństwa mogą kiedyś zupełnie zmienić swą nienawistną postawę i samemu przyjąć wiarę w Chrystusa - tak jak król Abenner. Dawało to nadzieję na nawrócenie muzułmańskich władców, zwłaszcza, że tkwili w mniejszym błędzie niż poganie, gdyż wierzyli w jednego Boga, a Chrystusa uznawali za jednego z proroków. Mimo że te nadzieje pozostały niespełnione - a samo Bizancjum w końcu upadło za sprawą wyznawców islamu - to Historia budująca o Barlaamie i Jozafacie nie pozostawiała wątpliwości, iż każdy pobożny chrześcijanin odbierze prawdziwą nagrodę po śmierci, przy której zbledną wszystkie ziemskie niedogodności.

\section{LITERATURA}

[Almond 1987] - Ph. Almond, The Buddha of Christendom: A Review of the Legend of Barlaam and Josaphat, „Religious Studies”, Vol. 23, No. 3, s. 391-406.

[Anderson 1997] - J. C. Anderson, Barlaam and Ioasaph, [w:] The Glory of Byzantium. Art and Culture of the Middle Byzantine Era A.D. 843-1261, eds. H. C. Evans, W. D. Wixom, The Metropolitan Museum of Art, New York, s. 242-243.

[Bádenas de la Peña 2015] - P. Bádenas de la Peña, La rédaction byzantine de „Barlaam et Josaphat", considérations sur la paternité et la composition, [w: Barlaam und Josaphat. Neue Perspektiven auf ein europäisches Phänomen, red. C. Cordoni, M. Meyer, Wydawnictwo Walter de Gruyter, Berlin-München-Boston, s. 1-19.

[Bolton 1958] - W. F. Bolton, Parable, Allegory and Romance in the Legend of Barlaam and Josaphat, „Traditio”, Vol. 14, s. 359-366.

[Bonarek 2011] - J. Bonarek, Bizancjum $w$ dobie bitwy pod Mantzikert. Znaczenie zagrożenia seldżuckiego $w$ polityce bizantyńskiej $w$ XI wieku, Wydawnictwo Historia Iagellonica, Kraków. (Notos - Scripta Antiqua et Byzantina 7).

[Borowska 2002a] - M. Borowska, Barlaam i Jozafat, [w:] Encyklopedia kultury bizantyńskiej, red. O. Jurewicz, Wydawnictwo Uniwersytetu Warszawskiego, Warszawa, s. 66.

[Borowska 2002b] - M. Borowska, Romans, [w:] Encyklopedia kultury bizantyńskiej, red. O. Jurewicz, Wydawnictwo Uniwersytetu Warszawskiego, Warszawa, s. 424-425.

[Ceran 2002] - W. Ceran, Iwiron klasztor, [w:] Encyklopedia kultury bizantyńskiej, red. O. Jurewicz, Wydawnictwo Uniwersytetu Warszawskiego, Warszawa, s. 223-224.

[Cordoni, Meyer 2015] - Barlaam und Josaphat. Neue Perspektiven auf ein europäisches Phänomen, red. C. Cordoni, M. Meyer, Wydawnictwo Walter de Gruyter, BerlinMünchen-Boston. 
[Der Nersessian 1937] - S. Der Nersessian, L'illustration du Roman de Barlaam et Joasaph, Éditions de Boccard, Paris.

[Holzberg 2003] - N. Holzberg, Powieść antyczna. Wprowadzenie, przel. M. Wójcik, Wydawnictwo Homini, Kraków (I wyd.: München 1986).

[Jeffreys et al. 1991] - E. M. Jeffreys, M. J. Jeffreys, A. Kazhdan, A. Cutler, Barlaam and Ioasaph, [w: ] The Oxford Dictionary of Byzantium, ed. A. Kazhdan, Oxford University Press, New York-Oxford, Vol. 1, s. 256-257.

[John Damascene 1967] - John Damascene, Barlaam and Ioasaph, trans. G. R. Woodward, H. Mattingly, Harvard University Press, Cambridge, MA-London (Loeb Classical Library 34), (I wyd.: Cambridge, MA-London 1914).

[Jurewicz 2007] - O. Jurewicz, Historia literatury bizantyńskiej. Zarys, Wydawnictwo Zakład Narodowy im. Ossolińskich, Wrocław-Warszawa-Kraków (I wyd.: Wrocław 1984).

[Kadas 1997] - The Romance of "Barlaam and Ioasaph", [w:] Treasures of Mount Athos, red. A.A. Karakatsanis, Wydawnictwo Holy Community of Mount Athos, Ministry of Culture, Museum of Byzantine Culture, Thessaloniki, s. 212-213.

[Kazhdan 1991] - A. Kazhdan, Euthymios the Iberian, [w: The Oxford Dictionary of Byzantium, ed. A. Kazhdan, Oxford University Press, New York-Oxford, Vol. 2, s. 757.

[King 2002] - U. King, A Response to Reflections on Buddhist and Christian Religious Practices, „Buddhist-Christian Studies”, Vol. 22.

[Lang 1967] - D. M. Lang, Introduction, [w:] John Damascene, Barlaam and Ioas aph, trans. G. R. Woodward, H. Mattingly, Harvard University Press, Cambridge, MALondon, s. IX-XXXV (Loeb Classical Library 34), (I wyd.: Cambridge, MA-London 1914), s. 105-112.

Lourié 2011] - B. Lourié, India "Far beyond Egypt": Barlaam and Ioasaph and Nubia in the $6^{\text {th }}$ Century, [w: Bibel, Byzanz und christlicher Orient. Festschrift für Stephen Gerö zum 65. Geburtstag, ed. D. Bumazhnov, E. Grypeou, T. B. Sailors, A. Toeppel, Uitgeverij Peeters en Departement Oosterse Studies, Leuven-Paris-Walpole, MA, s. 135-179 (Orientalia Lovaniensia Analecta 187). Leuven-Paris-Walpole, MA.

[Pelekandis 1975] - The Treasures of Mount Athos. Illuminated Manuscripts, Vol. 2: The Monasteries of Iveron, St. Panteleimon, Esphigmenou and Chilandari, red. S. M. Pelekandis, P. C. Christou, Ch. Tsioumis, S. N. Kadas, Wydawnictwo Athenon, Athens.

[Pitts 1981] - M. B. Pitts, Barlaam and Josaphat: A Legend for All Seasons, "Journal of South Asian Literature", Vol. 16, No. 1, Part 1, s. 3-16.

[Smorąg Różycka 1993] - M. Smorąg Różycka, Romans chrześsijański „Barlaam i Jozafat" w kulturze średniowiecznej Europy. Uwagi o dwóch miniaturach w „Ewangeliarzu Eawryszewskim”, „Slavia Orientalis”, t. 42, nr 1, s. 8-28.

[Toumpouri 2015] - M. Toumpouri, L'illustration du "Roman de Barlaam et Joasaph” reconsidérée: La cas du Hagion Oros, Monè Ibèron, 463, [w:] Barlaam und Josaphat. Neue Perspektiven auf ein europäisches Phänomen, red. C. Cordoni, M. Meyer, Wydawnictwo Walter de Gruyter, Berlin-München-Boston, s. 389-415.

[Woźniak 2015] - M. Woźniak, Wspólnoty chrześcijańskie na terytoriach opanowanych przez Arabów (VII-VIII w.), [w:] Bizancjum i Arabowie. Spotkanie cywilizacji VIVIII wiek, red. T. Wolińska, P. Filipczak, Wydawnictwo PWN, Warszawa, s. 428457. 
Magdalena Garnczarska

\title{
THE EDIFYING STORY ABOUT BARLAAM AND ILOASAPH AS AN EDIFYING STORY FOR CHRISTIANS LIVING UNDER MUSLIM RULE: ILLUSTRATED WITH AN EXAMPLE OF MINIATURES OF IVERON COD. 463
}

\author{
(Summary)
}

Barlaam and Ioasaph was immensely popular in Byzantium. The legend was inspired by Indian literature about the life of the Buddha and first appeared as a separate work in the $11^{\text {th }}$ century. Barlaam and Ioasaph has often been associated with saint John of Damascus, but this traditional attribution has been challenged, and Euthymius (d. 1028), abbot of the Iberian monastery on Mount Athos, has been suggested as the author of the Greek version. The Georgian version derives from the Arabic. This relationship reveals in textual and syntactic features.

Barlaam and Ioasaph relates the history of prince Ioasaph and his conversion to Christianity by the monk Barlaam, so the legend could give hope for the conversion of the Muslim rulers. The Iveron miniatures give a good insight into the legend. 